\title{
Early diagnosis of infected acute necrotising pancreatitis
}

\begin{abstract}
The aim of the work: to determine criteria for early diagnosis of infected acute necrotising pancreatitis.
Materials and Methods. The study was based on complex treatment of acute pancreatitis (AP) in 63 patients, who were divided into two groups: group I - with severe and critical AP ( $n=31)$ and group II - with light and medium severity rate of AP (n=32). All required laboratory and instrumental methods were made and some special, particularly the procalcitonin levels in the blood serum (group I). Determination of prognostic parameters was made through correlation analysis of all clinical parameters. The attention was paid to statistically significant factors that correlate ratio not lower than 0.7 (strong correlation).

Results and Discussion. The level of procalcitonin in blood $>3.7 \mathrm{ng} / \mathrm{ml}$ in first study group was those factor that showed the risk of developing more severe stage of pancreatitis with complications. Procalcitonin should be used as a marker of infected acute necrotic pancreatitis (ANP) in combination with other parameters of inflammation, which helps to choose the correct treatment.
\end{abstract}

Key words: acute pancreatitis; infected necrotizing pancreatitis; procalcitonin.

Problem statement, analysis of recent research and publications. The incidence of acute pancreatitis (AP) is from 6 to 14 per 100,000 population, representing 13-20\% of surgical patients [5]. In up to $20 \%$ of cases pancreatitis can be complicated by subtotal-total pancreatic necrosis with a total mortality from 20 to $80 \%$ [10]. AP ranks third place among the diseases of the abdominal cavity ranging from 5 to $16 \%$ [1,2]. Incidence of the AP over the last fifty years doubled and is still increasing all around the world, reducing efficiency of working people from 18 to 60 years (more often 30-50 years) Under 45 years men (69 \%) dominate [7]. This causes social importance of the problem $[2,4,5]$. Despite the use of modern diagnostic and treatment capacity, the overall mortality of ANP is very high and averages $10-25 \%$ and $25-$ $80 \%$ in sterile and infected ANP. Critical forms have mortality to $85 \%[5,7]$. Contradictory messages often appear in Ukrainian and foreign literature and it is difficult to find single doctrine of conservative and surgical treatment of ANP. Forecasting, a choice of indications and timing of surgery, techniques of operating procedures are those questions that are still opened [7]. The problem of non-invasive diagnosis of infected ANP is not fully solved, nevertheless instrumental imaging of the pancreas has reached a very high level [5]. Fast timely determination of the nature of the destruction of the pancreas and prognosis of the ANP is the possible solutions to the problem of treatment of this disease [5,9].

The aim of the work: to determine criteria for early diagnosis of infected acute necrotising pancreatitis

Materials and Methods. The study was based on complex treatment of AP in 63 patients, who were divided into two groups: group I - with severe and critical AP $(n=31)$ and group II - with light and medium severity rate of AP $(n=32)$. All required laboratory and instrumental methods were made and some special, particularly the procalcitonin levels in the blood serum (group I). Determination of prognostic parameters was made through correlation analysis of all clinical parameters. The attention was paid to statistically significant factors that correlate ratio not lower than 0.7 (strong correlation).

Results and Discussion. Among examined patients with light AP were 14 (22.22\%), medium severity AP - 18 (28.57\%), severe - 19 (30.15\%), critical - $12(19.04 \%)$ patients. Both examined groups included patients with different severity of AP: group I with severe and critical AP and group II with light and medium severity rate of AP. Medium age of patients was $(47.2 \pm 1.23)$ in the first study group and $(43.5 \pm 1.26)$ - in the group II. To establish the diagnostic and prognostic value of some laboratory parameters in patients of groups I and II were analyzed 34 indicators of individual body functional systems on the 1st, 2nd, 3rd, 5th,7th day of the disease. Group I had one more laboratory analysis - procalcitonin of blood serum. In the statistical analysis of the received material using the Student's test was evaluated the probability of the differences in these parameters in both groups. From all the 21 analyzed biochemical laboratory parameters were allocated 6 (amylase, diastase, ALT, AST, bilirubin, glucose), with aprobabledifference $(\mathrm{P}<0.05)$. Laboratory parameters (Table 1 ) in both groups were different. In the first group of patients at the time of admission was observed a significant leukocytosis 
Table1. Laboratory parameters in examined groups with probable differences

\begin{tabular}{||l|c|c|c|c|c|c|c||}
\hline \hline & $\begin{array}{c}\text { Amylase, } \\
\mathrm{U} / \mathrm{L}\end{array}$ & $\begin{array}{c}\text { Diastase, } \\
\mathrm{U} / \mathrm{L}\end{array}$ & $\begin{array}{c}\text { Glucose, } \\
\mathrm{mmol} / \mathrm{l}\end{array}$ & $\begin{array}{c}\text { Bilirubin, } \\
\mu \mathrm{m} / \mathrm{l}\end{array}$ & $\begin{array}{c}\text { ALT, } \\
\mathrm{U} / \mathrm{L}\end{array}$ & $\begin{array}{c}\text { AST, } \\
\mathrm{U} / \mathrm{L}\end{array}$ & $\begin{array}{c}\text { Leukocytes, } \\
\times 10^{9}\end{array}$ \\
\hline $\begin{array}{l}\text { Group I } \\
(\mathrm{n}=31)\end{array}$ & $563.005 \pm 32.5^{*}$ & $2747.199 \pm 434.58^{*}$ & $8.273 \pm 0.7^{* *}$ & $21.7 \pm 2.1^{*}$ & $108.3 \pm 11.2^{*}$ & $86.03 \pm 3.56^{*}$ & $12.5 \pm 0.85$ \\
\hline $\begin{array}{l}\text { Group II } \\
(\mathrm{n}=32)\end{array}$ & $70.15 \pm 8.6^{*}$ & $180 \pm 13.8^{*}$ & $14.6 \pm 1.8^{* *}$ & $15.6 \pm 2.3^{*}$ & $150 \pm 14.8^{*}$ & $107 \pm 10.5$ & $7.4 \pm 1.6$ \\
\hline
\end{tabular}

Note: ${ }^{*} \mathrm{p}<0.05$ - reliability data between the first and second groups ${ }^{* *} \mathrm{P}<0.01$ - reliability data between the first and second groups

in the blood and high level of cytolysis (the contents of AST, ALT). Significantly high amylase in blood and urine diastase showed the violation of exocrine function of pancreas.

The average level of blood amylase and urine diastase in both groups was the highest on the first day of the disease and reduced to 5-6 days. In both groups was tendency to hyperglycemia, which was alarming the violation of the endocrine function of pancreas.

Procalcitonin was determined only in group I. In the analysis of blood procalcitonin was found that in 18 patients (58.06\%) of group I (severe and critical AP) the levels of marker were increased (> $2.0 \mathrm{ng} / \mathrm{ml}$ ). Average level of procalcitonin in blood serum in patients who got surgical treatment first
3 days was (3.7 \pm 0.6$)$ (Table 2). In those 8 patients necrosis of pancreas and infected inflammation were evidenced on operation. Four patients who got surgical treatment after 3 days from beginning of illness had average level $(0.35 \pm 0.1)$, but necrosis wasn't formed and maybe surgical invasion shouldn't be made if it wasn't abdominal compartment syndrome. But intraabdominal hypertension (III stage $>20 \mathrm{~mm}$ of the water column) caused surgical treatment in these patients. Conservative treatment took place in 19 patients of group I with average level of marker: (2.3 \pm 0.56$)$. In general these patients had normal levels of marker or a bit higher and in last cases antibacterial therapy started. We think high level of procalcitonin needs fast time solution to

Table 2. Levels of procalcitonin $(\mathrm{ng} / \mathrm{ml})$ in blood serum in patients due to the time and kind of trearment in Group I

\begin{tabular}{||l|c|c|c||}
\hline \multicolumn{1}{|c|}{ Treatment } & Number of patients & $\mathrm{M} \pm \mathrm{m}$ & Probability of the differences \\
\hline Surgical treatment $<72$ hours & 8 & $3.7 \pm 0.6$ & $\mathrm{P}<0.05$ \\
\hline Surgical treatment $>72$ hours & 4 & $0.35 \pm 0.1$ & $\mathrm{p}>0.05$ \\
\hline Conservative treatment & 19 & $2.3 \pm 0.56$ & $\mathrm{p}>0.05$ \\
\hline Control & 10 & $0.87 \pm 0.23$ & \\
\hline
\end{tabular}

choose strategy of treatment, sometimes surgical, in another cases adequate antibacterial with controlling sensitivity by procalcitonin level. General condition of the body should be analysed in this choice.

General amount of patients who got surgical treatment (Table 3) was 26 (41.26 \%). Percent of surgical invasion was lower in group I in patients with severe and critical AP. We think this happened because of early use of procalcitonin marker at admission and correct conservative treatment including antibiotics which sensitivity was controled due to procalcitonin level.

Table 3 Surgical treatment in groups (number and \%)

\begin{tabular}{||c|c|c||}
\hline Group I & Group II & General \\
\hline $12(19.04 \%)$ & $14(22.22 \%)$ & $26(41.26 \%)$ \\
\hline
\end{tabular}

Levels of procalcitonin (Pic.1) in patients with medium severity of AP and with critical had differences. Patients with medium severity of AP had lower average level of procalcitonin than patients
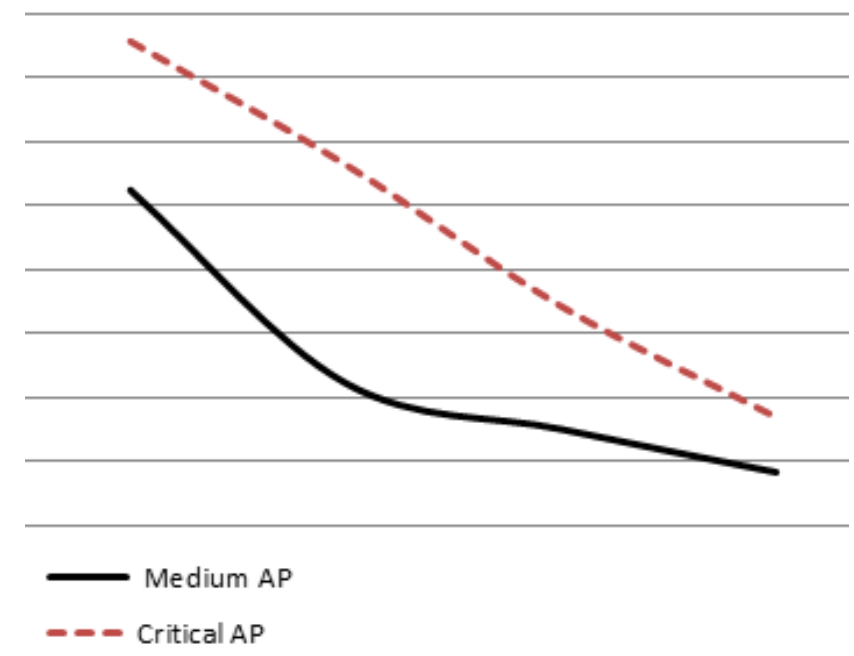

Pic. 1. Levels of procalcitonin $(\mathrm{ng} / \mathrm{ml})$ in patients with different severity of AP on different days

with critical and regression of procalcitonin was faster with medium severity of AP. 
It should be noted that the results of determination of procalcitonin stated that in patients in group I on the first, second, third day the marker was elevated in 11 patients (35.48\%). The blood levels of amylase, diastase urine and procalcitonin at admission correlated with the severity of pancreatitis showing the importance of these parameters in predicting the course of AP.

Ultrasonography at admission to hospital in patients of group I found changes in the pancreas that were characteristics of ANP in 21 patients (67.74 $\%$, these were patients with severe and critical ANP (the presence of sterile (peri) pancreatic necrosis). Ultrasonography in group II was informative in 17 patients (53.12\%). Computer tomography (CT) was performed in 16 patients in group I. High diagnostic value of CT in patients with critical ANP was in $75 \%$ (9 patients), with severe - in $63.15 \%$ (12 patients). But our findings are based on the comparative analysis of the diagnostic value of laboratory and instrumental methods of diagnosis in patients with AP. The next step to determine prognostic parameters was significant correlation analysis of all these criteria. After analyzing the data, we found that in determining the level of procalcitonin, amylase, blood glucose, and urine diastase in comparison with clinical parameters at admission had correlation ties. Correlation matrix of connections for each group consisted of 143 correlation coefficients. Most of relationships were formed by such factors as urine levels of diastase, the number of white blood cells, amylase in blood, glucose levels that correlated with each other and with other parameters of the system. Among amylase and diastase on the first day of illness correlations were: $\mathrm{r}=0.79$ in group $\mathrm{I}$ and $\mathrm{r}=0.7$ - in group II. On the third day: $r=0.81$ and $r=0.72$ in groups I and II. Procalcitonin had correlation not lower 0.6 and average $r=7-7.5$. It should be noted that parameters in the correlation matrix such as total protein, hemoglobin, urea and creatinine in serum did not form

\section{LITERATURE}

1. Petrov M.S. Organ failure and infection of pancreatic necrosis as a determinant of mortality in patients with acute pancreatitis / M. S. Petrov, S. Shanbag, M. Chakraborty [et al.] // Gastroenterology. - 2010. - Vol. 139. - P. 813-820 .

2. Petrov M. S. Conceptual framework for the classification of acute pancreatitis / M. S. Petrov, J. A. Windsor // Clin. Res. Hepatol. Gastroenterol. - 2012. - Vol. 36. - P. 341-344.

3. Petrov M. S. Infected pancreatic necrosis: not necessarily a late event in acute pancreatitis / M. S. Petrov, V. Chong, J. A. Windsor // World J. Gastroenterol. -2011. - Vol. 17. - P. 3173-3176.

4. Дронов А. И. Сравнение шкал ВISAP, АРАCНЕII, RANSON'S в прогнозировании тяжести заболевания и летальности при остром панкреатите /А. И. Дронов, Т. В. Лубенец, К. С. Бурмич // Український журнал хірургії.2011.-№ 5(14).- С. 39-41. strong relationships, so importance of these parameters in predicting the course of ANP was not big.

To clarify the diagnosis next days laboratory data were reevaluated. Such indicators as the number of white blood cells, urine diastase level, level of procalcitonin, blood glucose, correlated with each other, indicating high diagnostic value in determining those levels of laboratory parameters for early diagnosis of ANP.

Due to our results and facts of other studies there is still a wide area of researching the prediction of ANP and times of surgical treatment, so researchings in this theme must develop.

Conclusions. 1. Differentiation of inflammatory and inflammatory-necrotic lesions of the pancreas, complicated by infection, can be provided by traditional complex laboratory markers and also by procalcitonin certain level in the blood serum.

2. High level of procalcitonin needs fast time solution to choose strategy of treatment, sometimes surgical, in our research when level $>3.7 \mathrm{ng} / \mathrm{ml}$ and infected necrosis was evidenced in all cases.

3. Early use of procalcitonin marker at admission can prevent surgical treatment by adequate antibacterial therapy with controlling sensitivity by procalcitonin level.

4. All clinical symptoms in comparison with results of instrumental and laboratory tests should be used in diagnosis of ANP.

\section{Prospects for further research}

Too many views on treatment of AP in literature appear because of unpredictable course of the disease and small amount of diagnostic procedures in some cases. So, the role of prognosis of complications is very important. Procalcitonin like a marker of sepsis is only one key to establish such prognosis. New researches should include some more markers in comparison with procalcitonin, for example prosepsin. It needs new findings and studies.

5. Дронов А. И. Випадок успішного лікування хворого 3 важким деструктивним панкреатитом, ускладненим сепсисом / О. І. Дронов, Д. Б. Арешніков, Є. В. Дичаківський, А. М. Строкань // Біль, знеболювання і інтенсивна терапія. 2007. - № 1. - С. 45-54.

6. Патогенетичний підхід до лікування гострого некротичного панкреатиту / О. І. Дронов, І. О. Ковальська, В. Я. Шпак [та ін.] // Клінічна хірургія. - 2007.- № 9. - С. 25-27.

7. Дронов А. И. Гострий панкреатит: визначення, принципи діагностики та лікування / О. І. Дронов, І. О. Ковальська // Здоров’я України. -2010.-Тематичний номер.- С. 28-29.

8. Дронов А. И. Антибактеріальна профілактика в лікуванні гострого некротичного панкреатиту. Медичні перспективи / О. І. Дронов, І. Л. Насташенко, В. Ю. Уваров // Науковий журнал Дз “Дніпропетровська медична академія МОЗ Украї- 
ни.”- 2012.- Т. 17, № 1.- С. 112-211.

9. Захараш М. П. Хірургія: підручник / М. П. Захараш. - Вінниця : “Нова книга”,2014.- С. 184-215.

10. Капшитарь А. В. Лапароскопия в оптимизации хирургической тактики у больних панкреонекрозом /А. В. Капши-

\section{REFERENCES}

1. Petrov, M.S., Shanbag, S., \& Chakraborty, M. (2010). Organ failure and infection of pancreatic necrosis as a determinant of mortality in patients with acute pancreatitis. Gastroenterology, 139, 813-820 .

2. Petrov, M.S., \& Windsor, J.A. (2012). Conceptual framework for the classification of acute pancreatitis. Clin. Res. Hepatol. Gastroenterol., 36, 341-344.

3. Petrov, M.S., Chong, V., \& Windsor, J.A. (2011). Infected pancreatic necrosis: not necessarily a late event in acute pancreatitis. World J. Gastroenterol., 17, 3173-3176.

4. Dronov, A.I., Lubenets, T.V., \& Burmich, K.S. (2011). Sravnenye shkal BISAP, APACHE-II, RANSON'S v prognozirovanii tyazhesti zabolevaniyata letalnosti pri ostrom pankreatite [Comparison of scales BISAP, APACHE-II, RANSON'S in predicting the severity of disease and mortality in acute pancreatitis]. Ukrainskyi zhurnal khirurhii - Ukrainian Journal of Surgery, 5 (14), 39-41 [in Russian].

5. Dronov, O.I., Areshnikov, D.B., Dichakivskyi, Ye.V., Strokan, A.M. (2007). Vypadok uspishnoho likuvannia khvoroho z vazhkym destruktyvnym pankreatytom, uskladnenyi sepsysom [Case of successful treatment of a patient with severe destructive pancreatitis, complicated by sepsis]. Bil, zneboliuvannia $i$ intensyvna terapiia - Pain, Anesthesia and Intensive Care, 1, 4554 [in Ukrainian].

6. Dronov, O.I., Kovalska, I.O., Shpak, V.Ya., \& Tsymbaliuk, R.S., \& Uvarov, V.Yu. (2007). Patohenetychnyi pidkhid do likuvannia hostroho nekrotychnoho pankreatytu [Pathogenetic approach to тарь // Український журнал хірургії. - 2011. - № 3(12).С. 249-251.

11. Гострий некротичний панкреатит: сучасні підходи до хірургічного лікування / В. М. Копчак, І. В. Хомяк, К. В. Копчак [та ін.] // Харк. хірург. школа. - 2008. -№ 2. - С. 109-111.

treatment of acute necrotic pancreatitis]. Klinichna khirurhiia Clinical Surgery, 9, 25-27 [in Ukrainian].

7. Dronov, O.I., \& Kovalska, I.O. (2010). Hostryi pankreatyt: vyznachennia, pryntsypy diahnostyky ta likuvannia [Acute pancreatitis: definition, principles of diagnosis and treatment]. Zdorovia Ukrainy - Health of Ukraine, thematic issue, 28-29 [in Ukrainian].

8. Dronov, O.I., Nastashenko, I.L., Uvarov, V.Yu., Nastashenko, O.I., \& Lubenets, T.V. (2012). Antybakterialna profilaktyka v likuvanni hostroho nekrotychnoho pankreatytu. Medychni perspektyvy [Antimicrobial prophylaxis in the treatment of acute necrotic pancreatitis. Medical perspectives]. Naukovyi zhurnal DZ "Dnipropetrovska Medychna Akademiia MOZ Ukrainy - Scientific Journal of the State Institution "Dnipropetrovsk Medical Academy of the Ministry of Health of Ukraine", 17 (1), 112-211 [in Ukrainian]. Zakharash M.P. (2014). Khirurhiia: pidruchnyk [Surgery: textbook]. Vinnytsia: "Nova Knyha” [in Ukrainian].

9. Kapshitar, A.V. Laboratoskopiya u optymizatsii khirurhichnoy terapii u patsiyentov pankreonekrozu [Laparoscopy in the optimization of surgical tactics in patients with pancreatic necrosis]. Ukrainskyi zhurnal khirurhii - The Ukrainian Journal of Surgery, 3 (12), 249-251 [in Russian].

10. Kopchak, V.M., Khomiak, I.V., \& Kopchak, K.V. (2008). Hostryi nekrotychnyi pankreatyt: suchasni pidkhody do khirurhichnoho likuvannia [Acute necrotizing pancreatitis: modern approaches to surgical treatment]. Khark. khirurh. shkola - Kharkiv Surgeon School, 2, 109-111 [in Ukrainian].

Отримано 25.07.2018

\title{
А. І. БАНАДИГА
}

ДВНЗ “Тернопільський державний медичний університет імені І. Я. Горбачевського МОЗ України”1

Госпіталь імені Лістера, Стевенедж, Великобританія ${ }^{2}$

Госпітальний траст Королівського коледжу, Лондон, Великобританія

\section{РАННЯ ДІАГНОСТИКА ІНФІКОВАНОГО ГОСТРОГО НЕКРОТИЧНОГО ПАНКРЕАТИТУ}

\begin{abstract}
Мета роботи: визначити критерії ранньої діагностики інфікованого гострого некротичного панкреатиту.
Матеріали і методи. Дослідження базується на комплексному лікуванні гострого панкреатиту (ГП) у 63 хворих, які були розподілені на дві групи: перша група - 31 хворий з тяжким та критичним ГП та друга група - 32 хворі з легким і середнім ступенем тяжкості ГП. Проведено всі необхідні лабораторні та інструментальні методи, а також деякі спеціальні, зокрема визначення рівеня прокальцитоніну в сироватці крові (перша група). Визначення прогностичних параметрів проводили за допомогою кореляційного аналізу всіх клінічних параметрів. Увагу зосереджено на статистично значущих факторах, які корелюють співвідношення не нижче 0,7 (сильна кореляція).

Результати досліджень та їх обговорення. Рівень прокальцитоніну в крові> 3,7 нг / мл у першій дослідній групі був фактором, який показав ризик розвитку тяжчої стадії панкреатиту з ускладненнями. Прокальцитонін слід використовувати як маркер інфікованого гострого некротичного панкреатиту (ГНП) у поєднанні з іншими параметрами запалення, що допомагає вибрати правильне лікування.
\end{abstract}

Ключові слова: гострий панкреатит; інфікований некротичний панкреатит; прокальцитонін. 


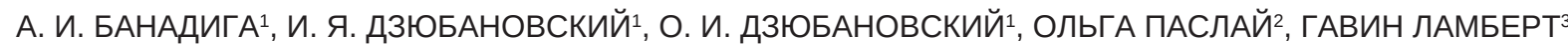 \\ гВУз “Тернопольский государственный медицинский университет имени И. Я. Горбачевского МОЗ Украины” \\ Госпиталь имени Листера, Стевенедж, Великобритания ${ }^{2}$ \\ Госпитальный траст Королевского колледжа, Лондон, Великобритания ${ }^{3}$
}

\title{
РАННЯЯ ДИАГНОСТИКА ИНФИЦИРОВАННОГО ОСТРОГО НЕКРОТИЧЕСКОГО ПАНКРЕАТИТА
}

Цель работы: определить критерии ранней диагностики инфицированного острого некротического панкреатита.

Материалы и методы. Исследование базируется на комплексном лечении острого панкреатита (ОП) у 63 больных, которые были разделены на две группы: первая группа - 31 больной с тяжелым и критическим ОП и вторая группа - 32 больных с легкой и средней степенью тяжести ОП. Проведены все необходимые лабораторные и инструментальные методы, а также некоторые специальные, в том числе определение уровня прокальцитонина в сыворотке крови (первая группа). Определение прогностических параметров проводили с помощью корреляционного анализа всех клинических параметров. Внимание было обращено к статистически значимым факторам, которые коррелируют соотношение не ниже 0,7 (сильная корреляция).

Результаты исследований и их обсуждение. Уровень прокальцитонина в крови> 3,7 нг / мл в первой исследовательской группе был фактором, который показал риск развития более тяжелой стадии панкреатита с осложнениями. Прокальцитонин следует использовать как маркер инфицированного острого некротического панкреатита (ОНП) в сочетании с другими параметрами воспаления, это помогает выбрать правильное лечение.

Ключевые слова: острый панкреатит; инфекционный некротический панкреатит; прокальцитонин. 